\title{
A Protracted Struggle: Rural Resistance and Normalization in Canadian Educational History
}

\author{
Mike Corbett
}

Their homes were worlds unto themselves. The fishermen were not nationalists of any sort, defined themselves as neither Newfoundlanders nor colonials, but residents of chthonic origin, sprung from the earth of whatever little island or cove they had grown up in. (Johnson 1998: 454)

"Good for you," said Grandpa as I stood with my mortar board and gown, clutching my various awards and diplomas... "Good for you," "ille bhigruaidh. This means that you will never have to work again." What he meant was that I would not spend my life pulling the end of a bucksaw or pushing the boat off the Calum Ruadh's Point in freezing water up to my waist. (MacLeod, 1999: 107).

Canadian rural historians Ferland and Wright (1996), Bouchard (1997), and Sandwell (1994) argue forcefully that Canadian historiography is shot through with a fundamental urban bias. Each claims Canadian rural history has been simplified and presented as a backdrop for the "real" history of the development of a modern urban, industrial nation. These historians argue for an analysis of the "continued importance of this numerically dominant rural population after industrialization" (Sandwell, 1994).

Canadian educational historiography is in a similar position. Although much of its subject matter is rural, differences between urban and rural schooling are often obscure. I wish to show that the history of rural education is as diverse as the various rural economies that span Canadian geography. Formal education entered rural communities substantially when these communities ceased to be labour-intensive, subsistence, or semiproletarian production sites. This transformation took place between the middle of the 19th century in southern Ontario but not until the latter decades of the 20th century in parts of rural Atlantic Canada, notably in Newfoundland. In many rural and coastal communities this part of what Raymond Williams called the "long revolution" is in its infancy if it has begun at all.

(C) Historical Studies in Education/Revue d'bistoire de l'éducation 13, no. 1 (2001): 19-48. 
The development of the Canadian educational state extends back to the 1830 s in Bruce Curtis's analysis of the history of the project of public schooling in Canada West (1988). Curtis draws on the work of Michel Foucault to reconceptualize educational history by challenging the traditional humanistic narrative of linear progress of the establishment of schooling. In Curtis's poststructural history, the aim of the educational project (which he calls the Canadian educational state) was to equalize and individualize, to shape children personally and collectively into uniform social subjects in the face of the rapid social change brought about by industrialisation.

In the eyes of 19 th-and early 20 th-century school promoters, modern society posed grave dangers to children, and, in turn, faced grave danger from "untrained" children (Donzelot, 1978). Beginning in the 19th century, a complex of institutions began to form subjectivities and to generate knowledge about how these subjects ought to see themselves, to appear, and to behave. Children thus came to be seen not only as individuals, but as individuals requiring direction; individuals who must be categorised and "educated," carefully, professionally and rationally, according to the "needs" and "capacities" of the individual child, to an appropriate social position made visible by a scientific scrutiny of human affairs and in the light of the needs of the emerging "modern" state.

The 19th-century dream of educational reformers and school promoters in Curtis's analysis is a managed social utopia constituted in schools by the administration of a "normalizing gaze" that would

strengthen the individual's focus and structure it such that 'reason' and 'intelligence' rather than 'passion' and 'impulse' would be dominant (Curtis, 1988: 102).

As a frontier society, Canada exhibited elements of this untamed nature and by the 1840 s, the state began making institutional inroads through such institutions as common schools, jails, and asylums. The rebellions of the 1830 s had shown the dangers of an uncontrolled populace in turbulent times(Axelrod, 1997: 21). ${ }^{1}$ Schools would become laboratories for social

'Axelrod $(1997,24-9)$ notes that in Canada West the educational state was supported by the Reformers and the Tories albeit for different reasons. For the Reformers it was a question of an "educated" democratic citizenship capable of making the kind of choices a free people need to make in the political and social arena. The promise of education might also teach the poor to be otherwise, contributing to social levelling, and class harmony. From the perspective of the 
engineering, where students would be fitted for "roles" in "society" (itself a novel 19 th-century idea born in part of revolutionary movements that had broken traditional power relationships and patterns of living and behaviour). The newly emancipated subject, the citizen/individual, would have to be taught to recognize this freedom as well as its nature and scope. Curtis writes:

Political conflicts were to be remade in the educational state through the remaking of political subjectivities. What is at work here is the making of (modern) social identities (Curtis, 1988: 13).

Thus began the long process of civilising and regulating ostensibly free subjects in developing capitalism. The kind of power necessary in this space was not dependent on overt coercion but rather on protracted training, against the backdrop of a rational normative social curriculum that inculcated appropriate perceptions and behaviour in the consciousness of the subject. The individualism demanded by humanistic pedagogy transformed the field into one of meticulous observation, shaping, and normalizing regulation.

The Normal is established as a principle of coercion in teaching with the introduction of a standardised education and the establishment of the Écoles normales (teachers' training colleges); it is established in the effort to organisea national medical profession and a hospital system capable of operating general norms of health; it is established in the standardisation of industrial processes and products. Like surveillance with it normalisation becomes one of the great instruments of power at the end of the classical age.... In a sense the power of normalisation imposes homogeneity; but it individualises by making it possible to measure gaps, to fix specialties and to render the differences useful by fitting them into one another. It is easy to see how the power of the norm functions within a system of formal equality, since within a homogeneity that is the rule, the norm introduces, as a useful imperative and as a result of measurement, all the shading of individual difference (Foucault, 1979: 184).

The end result is a putatively docile self-regulating subject who participates actively in his/her own subjugation. The trouble with Foucault's early work, perhaps best represented by Discipline and Punish, is that it paints too neat a picture of normalisation. This problem has been pointed out by various critics sympathetic and hostile to Foucault's post-structural reevaluation of historical studies and social analysis. Judith Butler analyses

establishment, schooling would provide the discipline necessary for a controlled kind of progress. Furthermore, the young could, at the same time, be indoctrinated in British Imperial ideology in the schools. 
the seeming paradox of the subject whose will is self-formed, tracing the idea of subjection from Hegel, through Nietzsche and Freud, to Althusser and Foucault (1997). Social theorist Anthony Giddens simply dismisses the idea that normalizing surveillance and meticulous subjection accomplishes all that Foucault claims for it $(1981,1995)$. In Giddens's words, "The 'docile bodies' which Foucault says discipline produces turn out very often to be not so docile after all” (1981: 172). Jürgen Habermas likewise advances the claim that had Foucault engaged his investigations in an analysis of the modern state (a striking absence in Foucault's work also noted by Giddens [1995:267-68]), he would have been forced to drop his notions of totalizing subjection in the face of advances in personal liberty, civil rights, and legal security that are difficult to deny (Habermas, 1996/1987: 290).

Other contemporary historians want to have it both ways and accept the general contours of Foucault's analysis of discourse and the radical conception of power which lies at its heart, yet rejecting the radical denigration of the subject Foucault implies. Citing the work of Canadian social historian Mariana Valverde (1991) on the social purity movement, Donald Wright (1995) claims she has adopted both elements of Foucault's hegemonic discourse without rejecting the creative power of human agency. This is accomplished through the use of the idea of resistance and the contention that every discourse generates a countervailing defiant discourse. Otherwise we are left with nothing but power and nothing more than an exercise in social control. Thus, resistance seems a useful formulation and provides a gap between social control and voluntarism in which historians and social analysts can operate.

\section{RESISTANCE IN THE HISTORICAL ANALYSIS OF CANADIAN RURAL SCHOOLS}

At the heart of the various critiques of Foucault is a general thread of resistance. Things do not always turn out as neatly and as predictably as the normalisation project, particularly in Foucault's early books, imagines. Totalizing theory, and the social practice and institutional work that accompanies it, generate resistance. In a recent analysis of the ascendancy of liberal democracy in Western popular culture which has as its benchmark the supposed "end of history' (Fukuyama, 1992) and the final defeat ofMarxism with the demise of the former Soviet Union, Jacques Derrida invokes the language of what he calls "spectrology," or the persistent, haunting presence of resistance to totalizing ideology throughout the work of Marx (Derrida, 1994). For Derrida, resistance is a constant fly in the 
ointment of theory. Whenever the claim is made that a particular direction must be taken, indeed that history demands it, recalcitrant and not-sodocile subjects and chaotic events resist.

This was not lost on Foucault. His studies were typically concerned with the local intricacies of resistance to normalisation in concrete historical studies while documenting its formation. In the end, for Foucault, the structured practices of normalisation conquer the resistant subject if only because a successful resistance becomes a new regime of truth. Yet as de Certeau (1984) and Deleuze (1988) contend, resistance is at the very core of power relations in Foucault's writing. Post-colonial thinkers have used the idea of resistance to theorize the way oppressed groups carved out space in colonial regimes, ultimately subverting them (Bhabha, 1994; Gilbert, 1997; Ashcroft, Griffiths and Tiffin, 1995). Power is always faced by its other, never entirely transforming it. In Canada, scholarship in educational history is showing the way the state used schools to normalize various populations including First Nations people (Barman; Miller, 1996; Archibald, 1993), women and children (Creese and Strong-Boag, 1992; Gleason, 1999) and immigrants (Stanley, 1990; Kach and Mazurek, 1994). ${ }^{2}$

I wish to show there is evidence in the history of Canadian education that rural resistance was a persistent irritant in state formation. Indeed, much of Curtis' analysis is taken up with documenting popular and institutional (often community and church led) resistance to the Canadian educational state. An important strain in Canadian educational history argues it was the structural incompatibility of rural economies and the (industrial) routines of schooling that led to weak penetration of state schooling in many rural areas. Yet Curtis maintains rural resistance cannot be attributed exclusively to the structural differences between the taskoriented rhythms of agricultural and resource-based economies and the factory-model work routines of the school.

Although rural resistance to normalizing through state schooling is by no means universal, one aspect of the "rural school problem" was (and continues to be) real or imagined irrelevance of the institution and urban bias in it. Operating from Curtis's Foucauldian analysis of schooling as part of a "tutelary complex" (Donzelot, 1978), that complex of state institutions designed to shape subjectivity, I here review sources on resistance in rural schools. I show that the content of schooling, and the structural incompatibility of school and rural work, are both necessary to

${ }^{2}$ I would argue that current struggles over First Nations access to resources and control of land represent the development of a strong resistance to the legacy of oppression that Stanley characterises as "white supremacy" (1990). 
explain persistent rural resistance to the routines of formal schooling. Resistance takes two main forms: 1 ) the rural subject stands in opposition to schooling on the grounds that it is/was often an irrelevant urban/outside imposition (rurality in resistance); and, 2) structural resistance, that is, rural regions and their typical economic activities are at odds with the structure of schooling (rurality as resistance). ${ }^{3}$

Curtis's analysis of state formation presents schooling as part of an institutional apparatus designed to inculcate and routinize work discipline and habits in a uniform social subject that might be "useful," compliant, and self-regulating in the integrated and rationally organized industrial economy. But as Wilson and Stortz have shown, rurality embodies difference and variability that persist in the face of unsuccessful and even misguided normalisation efforts (for instance, "rural mindedness," progressivism, and the ideology of practicality, agricultural education, normal, and summer school training for in-service and prospective teachers) possible in the remote rural school staffed by isolated and typically inexperienced young teachers (1993).

In rural circumstances, the teacher as instrument of state leverage and purveyor of "civilisation" and "improvement" often failed and teachers were forced to adapt to community realities or perish. Although more urban locales such as Victoria or St. John's had by the early $20^{\text {th }}$ century well-developed institutions charged with the work of subjectification, remote areas were still independent, "untamed," immersed in the localized resource extraction economy, resistant to "outside interference" and state intervention in general. It was and continues to be easy to resist protracted formal education in rural economies, particularly for young men. What schooling offers is often a pale shadow of working class adult responsibilities, incomes and privileges which can only be "bought" through employment.

\section{RURALITY IN RESISTANCE}

Curtis argues that resistance to schooling cannot be interpreted as the deviant actions of individuals isolated from the moral standards of the community. Rather, what develops through the decades leading up to compulsory attendance legislation (and even after) is a struggle over the

\footnotetext{
${ }^{3}$ Postcolonial theorist Bhabha (1994) uses the concepts "transitive" and "intransitive" to distinguish between overt and immanent forms of resistance. Rurality in resistance is transitive while rurality as resistance is intransitive.
} 
contested territory of the school, which is the territory of subject formation in a predominantly rural society. Curtis writes:

Rather, in cases where students had the support of other community members, opposition may be seen as resistance in the face of political initiatives directed against popular character and popular culture (1988: 156).

For Curtis, resistance meant that children might not attend, nor would events inside school necessarily follow prescriptions (Curtis, 1988: 146). Before the 1850s, Curtis argues, schools were locally controlled and generally followed community values. The School Act of 1850 in Canada West effectively enshrined schools as a means of "civilising' and 'improving' local populations," and where "pedagogical activity was radically different after 1850" (Curtis, 1988: 159). The new schooling presented a curriculum of moral regulation effectively striving to "replace the family," (and the community) subsequently placing children under state control (Curtis, 1988: 201).

School promoters in the last half of the 19th century were to lay the groundwork for habits and regularized social practices required for industrial routines. Regular attendance of children was thus an essential preoccupation. Regularity of attendance implied regularity of character in a population still attuned to the rhythms of seasons (Gaffield, 1987; Davey, 1978). Curtis speaks of this emphasis in terms of Durkheim's "moral constancy," claiming that school attendance was prerequisite to the enterprise of moral regulation through schooling. Curtis writes, "Regularity in school attendance was to produce regularity and stability in more general behaviour patterns, particularly in political behaviour" (1988: 183). Attendance became the locus of moral training as opposed to older forms of community controlled educational systems which were, "a locally controlled convenience adapted both to community needs and community desire" (Curtis, 1988: 199).

Curtis argues that the literature on structural conflict between rural labour and schooling, with its uniform work time as opposed to "task orientation" in rural communities and on farms, neglects resistance to the content and practices of schooling (1988: 187). Curtis does present clear evidence that this is so, but there is further published work showing that the rhythms of work, and the structure of everyday life in pre-industrial and rural industrial communities chafes against the formal structure and processes of schooling (Lucas, 1971; Corbett, 2001). Most oral histories and investigations in the tradition of social history (which take seriously the accounts of ordinary participants) of rural schools and schooling from the first half of the 20th century contain similar stories of community and student resistance (for example, Smith, 1996; McCann, 1982; Wilson, 1995; 
Stephenson, 1995). Rural people resisted the long arm of the state, reaching into the public and private spaces of their lives. But it is the structure of work and life in rural communities that grounded this resistance in a reasonable lived alternative.

This alternative was simply the call of everyday, out-of-school life which, when available to rural students, has always proved too strong for many young people to resist. Earnest, yet alien projects of social normalisation promised 'options,' emancipation, and integration into a larger more interesting society and future riches associated with integration. ${ }^{4} Y$ Yet school was resisted because it was a kind of infantilizing "foolishness" identified in rural Nova Scotia by a Sterling County Study informant in the 1950 s as all right for children but not for young men and women (Hughes, et. al., 1960). School was understood to be disconnected from life, standing in the way of maturity and the assumption of adult roles and responsibilities. In rural places, well into the present century, the opportunity to join the adult community as a full participant was available to children at least as young as thirteen or fourteen. ${ }^{5}$ This resistance to schooling, which amounted to

${ }^{4}$ A rural school administrator in Nova Scotia once told me that the fact of one person with a university education working in the local fish plant makes a more powerful statement about the value of education in the community than a hundred successful graduates living and working elsewhere but whom nobody in the community sees

The gender dimensions of rural schooling deserve more attention. I have found that in a Nova Scotian coastal community in the period between 1957 and 1998, young women stayed in school longer and were more academically successful than their male peers (Corbett, 2001). This, I argue was in large part due to the lack of opportunities for women in the gendered occupational structure of local primary industries. Since "girls just didn' $t$ " work in the woods or on fishing boats, and young women were faced with certain economic dependence and social marginalisation should they leave school early and "stay" in the community. For many women in my study, education was useful because virtually all independent future options required secondary education at the least, and outmigration.

${ }^{5}$ Curtis analyses the conflicted development of the modern school in which it is generally (although not universally, particularly in the current legitimation crisis of the public school project) assumed that parents should hand their children over to professional educators to be educated in the formal places we now know as schools. From an urban perspective this normalisation was essentially complete by the $1920 \mathrm{~s}$ and schools had assumed a "formal" structure and nearly universal acceptance (Sutherland, 1990; 1995; 1995b). Curtis sees this as a struggle which recalcitrant communities were doomed to lose to the rational administrative project of public schooling that eventually emerged in the 20th Century. Curtis phrases it this way "Community regulation of the school was markedly weakened by the increasing solidity of administration and by increasing density of administrative relations. But community intervention remained common.... Only in the early 20 th Century did 
the call of maturity and full economic and social participation, was effectively quashed by remaining in school. In this context, school is a frivolous place where "children" are kept as children.

Many students, furthermore, were full fledged and largely independent members of the local community actively engaged in labour processes as soon as their physical capacities permitted. Schooling, by contrast, constructed youth as "children" to be governed by an alien "necessity," determined by anonymous others and imposed on them for their "own good" (Curtis, 1988: 199).

This is a crucial point in Curtis's argument. Only when parents "voluntarily" consent to public schooling can it succeed. The source of power comes not at the point of coercion, but on the contrary, at the point where coercion is no longer necessary because the subject has consented. Only then does disciplinary power begin to do its work. Overt force undermines the key element of consent, for

Only if parents consented to act in concert with the school in the subordination of 'children,' only if scholars consented to becoming 'school children' and accepted the process of training would schooling entirely succeed (Curtis, 1988: 342).

Yet this acceptance or denial of the importance of schooling needs to be understood in time and place.

\section{RURALITY AS RESISTANCE}

\section{CanadaWest/Ontario The establishment of public schooling}

Curtis's analysis of the development of the Canadian educational state provides a theoretical framework for understanding resistance to schooling. There are, however, difficulties in his account. Although he speaks of rural communities, and most of his accounts are from rural areas, Curtis does not see rurality itself as "problematic." His account details the conflict between administrators and school promoters and often resistant ordinary individuals and groups upon whom this vision was imposed. Curtis comes close to dismissing analysts who see rural communities and rural life as the motor of resistance to schooling.

Curtis is, I think, correct to argue that the development of industrial capitalism required a meticulous kind of subject formation. However, another critical problem is that the development of industrial capitalism is

such 'good parents' (willing to support school discipline) become (sufficiently) common (1988: 356). 
not just concerned with the internal colonisation of the subject, but also with the colonisation of space. Urbanisation is intimately connected to the development of capitalism and the state itself. As Giddens writes, "without cities, there are no classes and no state" (1981: 144), and further that, the administrative order of the state in class-divided societies never penetrates the traditional organisation of local agrarian communities in the same manner as occurs subsequent to the development of capitalism (1981:145).

Drawing on a strand in Marx's thinking about the development of capitalism, Giddens attends to the geography of capitalism as progressive "urbanisation of the countryside" (1981: 148) designed to "disembed" locally-oriented subjects and to draw into the ambit of capitalism increasingly wider spaces by extending the commodification of space out of the city and into the countryside. The problem here is that large parts of Canadian geography had not been institutionally penetrated by the state until the latter part of the 20th century.

Further, state penetration often remained ineffective as subject formation because of the typically non-standard form rural capitalism has taken. Many independent petty producers remained for many years (and remain) efficient in their unavoidable rural isolation (Brym and Sacouman, 1979; Matthews, 1976; Kearney, 1993; Johnson, 1999). In parts of Northern British Columbia, Northern Ontario, and in coastal fishing communities of Atlantic Canada for example, this partial isolation from institutions of normalisation shapes a particular kind of real and imagined independence that generates and supports development of local culture and community specific class structures and profitable capitalist work relations at the same time. I have described one such cultural space, where the exigencies of the local economy were dominated by petty production until well into the 1980 s and formal secondary schooling remained a peripheral preoccupation for most young men (Corbett, 2001).

Localized culture was the object of the attention of the rural school promoter. As capitalist social relations penetrate and transform a subsistence economy, space and people have to be managed. Curtis and others as diverse as Strong-Boag, Wilson, Davey, and McCann document the role of rural schools in the vanguard of capitalist modernisation of "backward" places, and the people who live in them. Yet it must be said that this urbanisation of the countryside is neither a linear process nor is it yet complete.

The normalizing of schooling operates more effectively in the context of urban spaces, already colonized by linear constitution of space and work time. Simply by their resistance to becoming engineered spaces, rural areas were sites for the development of localised identities, community, and idio- 
syncratic forms of resistance to the project of schooling. ${ }^{6}$ In rural communities with relatively simple divisions of labour, where many workers performed similar if not the same kinds of work, and particularly where this work was connected closely to the land and to resource extraction, the productive activity itself may require a certain "freedom" that generates resistance to formal state normalisation through schooling. Curtis fails adequately to understand the resistance implied by the productive and spatial structure of the rural community.

Ian Davey's groundbreaking study of attendance records in the schools of Canada West between 1851 and 1871 illustrates this problem (1978). Davey shows that despite apparent acceptance of the idea of the common school, the practice of school attendance was sporadic. Davey explained this by the pressing need of families to work (moving about to do so in many cases) and to survive in difficult conditions of boom and bust. Contrary to the myth of rural stagnation and immobility, country life has often meant frequent migration and multiple occupations. Trade depressions, crop failures, transient work patterns and seasonal employment made schooling nearly impossible even for parents who sincerely wanted their children in school. The schoolmen blamed "the migratory 'habits' of the working class (which) were perceived as part of their general want of discipline along with their impunctuality, irregular work habits, affection for alcohol and inability to save money" (Davey, 1978: 233), but it was clear that the lessons of work and mobility were taught in the school of life. In seasonally urgent work, "farmers' reliance on their children's labour was almost universal," particularly for older children (Davey, 1978: 239). ${ }^{7}$ As for children themselves, Davey hypothesises that there was a fundamental contradiction

${ }^{6}$ It can also be argued that because rural spaces often have to be wild to be productive, created or managed space takes on a different form in rural environments. For example, Pocius argues that socio-spatial identity formation in Newfoundland coastal communities has been crucial to exploitation of resources on land and sea (1991). In his ethnographic analysis of life in a coastal village a large part of the education of young men and women is taken up in the development of intimate knowledge of gendered productive local spaces. Because they have acquired this knowledge, Pocius shows that people are much less likely to leave the village or to do formal education in other (urban) places. Others have made similar arguments (Berry, 1977; Theobald, 1997; Creed and Cheng, 1997; Corbett, 2001).

'Quoting a primary source of the day, Davey notes that the "older boys" (aged 16 to 20) in many farming communities would of ten return to school in the winter months, "to peruse old studies and make further advancement" (Davey, 1978 241). A more likely reading of this behaviour is that rather than returning to peruse old studies, these lads were no doubt returning to peruse a new schoolmarm. 
between seeing people prosper by "muscle and cunning" and the hollow promise of freedom from toil that schooling offered (Davey, 1978: 245).

Gaffield (1987) presents a similar picture for settlers in Prescott County in Eastern Ontario, where children were intimately connected not only to family life but played an important economic part in it. Gaffield describes a labour-intensive attempt to achieve survival and security, most Francophone children worked at home, in the woods and perhaps at the mills. School was simply not important ... most Francophone children were simply producers not pupils $(1987: 110)$.

By the 1880 s work was less pressing, particularly for younger children. As a whole, "the local economy offered less productive opportunity for children" (1987: 93). This is not to say that attachment to the land and to the family as the principal social unit did not remain strong as the système agro-forestier functioned in part as a collection of family economies that sought full participation from every family member. Therefore the experience of childhood involved integration into productive activity. (Gaffield, 1987: 97).

Gaffield argues schooling became routine only when rural communities and farms were sufficiently established to spare child labour, and then only until these children grew strong enough to find "real" work of their own. It was absence of work that made school important. For large numbers on the uncertain margins of rural subsistence poverty, this day never arrived.

\section{British Columbia: Agricultural education and the rural problem in the early $20^{\text {th }}$ century}

As Canadian agricultural society developed and mechanised, the land no longer required or invited child labour. Nonetheless, in rural areas and in developing urban metropolis, "country life" was thought nourishing and "natural" in a way city life could never be. Nostalgic and simplistic memories of $19^{\text {gh- }}$ century manual farming meant agricultural education in British Columbia before 1930 was doomed to fail (Jones, 1978). In the agricultural education movement we see the convergence of the normalizing project of schooling and community-grounded agricultural experience. Jones asserts that schooling "actively worsened the rural problem by facilitating movement from the land" (1978: iii). The agricultural education movement peaked with the federal Agricultural Instruction Act in 1913. The Act was designed to promote school agricultural programs as a way to valorise rural experience in the eyes of country children and to purify the lives of urban children who lived in the dirty, unnatural bustle of the industrial landscape. 
Somewhat ironically, Jones claimed this resistance arose in some part because agricultural education ran counter to the social and economic stigma against agriculture. Many parents saw schools as "theoretical places" and were more concerned with seeing their children taught the $3 R$ 's rather than things they could learn from life without formal instruction. As Jones suggests, "not everyone was pleased with the notion that school and community ought to be doing the same things" (Jones, 1978: 333). Still, this sentiment does support the conclusion that rural inhabitants saw the school as separate from life in the community, and perhaps also, that in its separateness the school was claiming a higher ground onto which the student might be "elevated." I think there is evidence to suggest that this view and the underlying reality of refined and "alien" urban teachers and their "aura of mystery and sophistication" (Wilson and Stortz, 1993 286) has considerable credence. One could hardly expect such strange, transient butterflies to inculcate much of a sense of "rural mindedness" in country students or show them much about the work on the land from which they and their families wrested a living. ${ }^{8}$

After the First World War, progressivism led British Columbia school administrators to give special consideration to what they termed the "rural school problem" (Wilson and Stortz, 1995). In response to dismal conditions in rural schools, the Putman Weir Commission of 1924 tackled rural schooling directly. During the 1920 s British Columbia administrators embarked on systematic extension of state education to far-flung areas by training and placing progressive "rural-minded" teachers in remote communities; seeking to retain teachers in communities for longer periods; and providing better pay for rural teachers (Wilson and Stortz, 1995: 216-27). The Putman Weir Commission adopted Deweyan ideas, exhorting teachers to begin with the experience of the child. In the rural school that meant teachers and curriculum workers would pay attention to the place where experience occurred, the rural community. The rural teacher in this scheme was expected to become "a socialising agent" in the community, a civilising force, the representative of the educational state in remote areas (Wilson and Stortz, 1995: 212). These teachers found rustic frontier communities where families required their children to work and where attendance was sporadic. Rural teachers typically became pawns in local power games, not community leaders. Wilson and Stortz write that, " [Although] Victoria

\footnotetext{
${ }^{8}$ [ began my teaching career in northern Manitoba in the early 1980 s. In response to a progressive education initiative that would have Northern Cree students study First Nations culture in the school, one trapper responded, "I'll teach my kids to read tracks in the snow, you teach them to read tracks on paper."
} 
expected [the] teacher to serve as a community leader, at the local level she tended to be looked on as a community servant" (1993:282). Wilson and Stortz considered the project entirely ill-conceived, "fundamentally misguided" (1993: 286), immensely ignorant of rural realities, and its teachers poorly trained and paid.

In almost complete isolation, inexperienced young teachers faced everything from a lack of school resources, to poverty and lack of food and clothing for children, to second-language difficulties, to hostile communities, to disease, to cooking for and hosting community parties, to playing off competing interests in the community and negotiating social space between rival families, to children more interested in what the local farmers were doing than getting to school (Wilson and Stortz, 1993; Stephenson, 1995; Smith, 1996). A former teacher recalled:

I asked the other pupils about this boy's 'punctuality', or lack of it, to which they replied that they could not remember when he had arrived on time. He loved to chat and visit farmers at work in the fields and would often ride on the tractor with them (Smith, 1996: 74).

For many children in rural communities, life beckoned. Wilson and Stortz comment that although compulsory schooling was legislated in British Columbia in 1921, it had little effect in frontier communities in the remote North Central region of the province (1993: 277). ${ }^{9}$

Neil Sutherland finds a similar pattern of child labour and sporadic school attendance in frontier communities established as recently as in the late 1950 s $(1995 a) .{ }^{10}$ On the basis of oral history interviews, Suther

${ }^{9}$ Rural sociologists have made similar claims in the 1990 s arguing that much of the literature in educational sociology is urban-biased, presenting a picture of Canadian society that ignores the fundamentally different structure of opportunities and forms of cultural capital available to rural youth. See Looker (1993) and Looker and Dwyer (1998) for a discussion of this problem with respect to the sociology of educational aspirations and attainment. Jones provides similar analysis in her investigation of migration and educational decision making of rural youth in England (1999a, 1999b). Seyfrit and her colleagues have also analysed analogous questions in Alaska and in coastal Virginia (Seyfrit, 1998; Seyfrit and Hamilton, 1997; Seyfrit and Danner, 1999).

${ }^{10}$ In urban areas Sutherland finds a similar, if less pronounced, relationship between school, work, and community life. Confronting the assumption that the problem of child labour was eliminated with industrialisation and child labour legislation, and at the same time suggesting that historians reappraise the place of work done by children in their socialisation and broad education, Sutherland suggests that work played a significant part of childhood experience in Vancouver until at least the 1960s, often competing with school (1990). Work, in and outside the home, remains central in the lives of children in the industrial age. It is not until 
land describes a childhood filled with incessant toil like that of pioneer children throughout modern Canadian history. Children were generally considered "useful" at eight years of age and capable of doing adult work by the age of sixteen (Sutherland, 1995a: 139). Children's free labour in large part built many homesteads. Despite a brutal regimen of work in, "a community in the throes of creating itself"(Sutherland, 1995a: 125) and the obvious tension between the need for a child's labour and the demands of schooling, Sutherland found that by 1921 attendance in elementary schools had stabilized at around $90 \%$ provincially, where it would remain until into World War II. By 1939-40 average provincial attendance in high schools had reached 90\% (Sutherland, 1995a: 127). In frontier communities, though, students still stayed out of school at key times, but otherwise balanced an onerous work-study routine. Sutherland (1995a) makes the point that work on the land provided young people with an important informal education for the lives most ended up living in communities on the northern agricultural fringe. Sutherland's analysis does not differentiate between rural and urban attendance statistics.

\section{Québec and Newfoundland, 1930-70}

In a recent article Southcott has argued that the study of regional inequality outside Québec has been stalled by an inability to get around theoretical debates between modernization-and dependency-theory accounts of Canadian rural development(1999). This has led to denigration of matters of cultural and identity and preoccupation with structural analysis. Because identity and culture have been central preoccupations of Québécois intellectuals, a similar impasse has not developed to as great an extent in sociological and historical studies there. Even so, Bouchard argues there are significant weaknesses in historical studies of rural Québec (1997). He writes that neither a liberal analysis of industrialization displacing rural community, nor a Marxist dependency model of uneven development, explains rural development in Québec, for both assign the rural economy a marginal status. Thus, Bouchard argues, historical accounts document

the 1960s that significant structural changes occur to free children from the necessity of helping their families economically and physically with menial work now done mainly by labour saving devices and replaced by automatic heating sources like gas, oil, and electricity. However, Sutherland claims that schools were regularly attended by the vast majority of children between the ages of 5 and 16 from the 1920 s, an apparent contradiction. 
allegedly important changes in the urban metropolis assuming rural areas follow apace or remain stereotypical backwaters.

Out of the long history of social and economic transformation in Canada, Bouchard argues Canadian historiography has developed a notion of rational agribusiness as the pinnacle of normal rural development in an "ideal type of capitalism" (1997: 32). This stereotype of rational capitalist development sits in opposition to the community-based, backward, precapitalist farmer. Both constructions obscure the complexity of people who lived in rural and urban communities. He calls for a critical review of "the historiography of the English Canadian, and more particularly, the Ontario farming economy" (1997: 32).

Bouchard examines the history of the Saguenay region, finding a multiple relationship between rural communities on one hand, and family agricultural operations on the other. Bouchard investigates rural community development in terms of the strategies of rural dwellers to maintain family autonomy and prosperity all the while benefiting from capitalist social relations and wider forms of trade. Bouchard documents the transition from a traditional rural economy to what he calls co-integration with the modern economy where significant aspects of family production, expansion of land settlement, and multi-activity linkages with wage labour of various kinds, to more recent total integration into the capitalist economy. Schooling did not play a significant part in the development of the traditional rural economy for the majority of Québecois, but Bouchard cites the entrenchment of compulsory schooling between 1930 and 1950 among the chief factors in the demise of the co-integrated community. Bouchard found strong support for schooling in rural Québec dating at least to the 1930s, "when the construction of a school was hailed with the same enthusiasm as a new road or even a hospital" (1997: 30).

Through the transitional period which marked the movement from cointegration into what Bouchard calls more complete integration of rural people into wage labour, a generation was lost (1997: 30). Lacking either the access to land that allowed success in the co-integrated economy, or the education necessary in larger labour markets, an intermediate "lost generation" was a major force propelling social change. Because this "lost generation" was compelled by social and economic transformation, they saw the importance of education as a source of cultural capital for their children. The rural poor understood the change around them and pushed their children through education. These lost-generation parents effectively "shunted" their children toward urban areas and opportunities in the integrated urban communities that were developing rapidly in Québec after World War II. If there was resistance to the expansion of educational 
opportunity in Québec society between 1930 and the 1950s, it came from the entrenched elite. This transitional generation was

... a major force for modernisation. It is that generation that suffered most from the minimal education that had been the norm up until then ... the changes brought about by the quiet Revolution were long desired by the grass roots; it was precisely at the top of society that there was resistance. (Bouchard, 1997: 30)

Bouchard suggests fishing communities could also be analysed in terms of co-integration. ${ }^{11}$

\section{McCann's analyses of the slow entrenchment of schooling in Newfoundland}

In many respects Newfoundland has been, until recently, a frontier society despite a long history of settlement. McCann suggests the task of building the educational state in Newfoundland is just beginning (1994). Before the 1940s, participants in McCann's (1982) oral history project describe a "fisher-folk" society outside St. John's and the industrial communities that appeared after World War II. This is a society of fishing people outside the reach of the state. ${ }^{12}$ For McCann, the result was an education system arcane in structure (with church-controlled education, eliminated by legislation only in 1997).

Explaining Newfoundland schooling in light of economic history, McCann (1994) expected to find the progress of schooling would mirror that of the economy and have a "direct correlation." What he found was a more diverse picture interacting economics, religion, and politics, all serving to shape Newfoundland's public educational experience. In the 19th century Newfoundland was a colonial society from which a significant proportion of surplus capital was drained, leaving few public funds for

"Bouchard writes "In fishing areas the sea plays quite the same role as fallow land, as an apparently unlimited pool of resources; there is often the same seasonal employment pattern, the same multi-activity and so forth" (1997: 34).

${ }^{12}$ For an critical analysis of the idea of the "folk" in Nova Scotian cultural affairs in the 20th Century see MacKay (1994). MacKay argues that Nova Scotians constructed themselves and were constructed as pre-modern rustics promoting a kinder, gentler way of life for the consumption of Ontario and American tourists seeking to escape the stress and strain of modernity. The image of the fisher folk is central to this construction but it in no way represented accurately Nova Scotian society in the 20 th or even the 19 th Century when, as MacKay comments the average Nova Scotia worker was far more likely to be a service, coal, steel or factory worker than a fisherman. 
schools (McCann, 1994: 244). Internal colonialism and an urban-rural divide created conditions for vastly unequal access and quality of schooling.

McCann saw a consistent pattern of government neglect of education until Confederation in 1949. The Newfoundland state simply did not interest itself in normalisation and development of modernizing institutions like school. Governments could not see the advantages of a literate and educated population as the foundation of personal development, social innovation, energetic intellectual debate and invigorated economic and political life, or as an element in the development of a "nationally imagined community" (McCann, 1994: 248). ${ }^{13}$

In the rural areas the problems of the pre-industrial character of the fishery through the early decades of the current century, the devastating impact of Depression and war left Newfoundland schools in the 1940s in little better shape than in the early part of the century, or even in the latter part of the 19th century. Inspector Ralph Andrews, whose career in education spanned the 1930s and 40s, described subsistence in rural communities where children had to work and where school life fitted seasonal rhythms. It was traditional in some areas for children not to go to school "until after the potatoes were picked [in October]" (McCann, 1982: 65). McCann comments:

[E]ducation for its own sake-as might be expected in a society in which

a living from the sea had to be wrested by hard work-was less valued than

a belief in the importance of practicality in everyday life(1994: 250).

There is little in McCann's analysis to suggest that this had changed substantially into the 1950 s.

The call of everyday life, following declining fish prices and a contraction in the fishery before 1940 , opened out into other resource extraction opportunities in the mines, in the woods, and in the mills and foreign-owned companies established in Newfoundland to exploit landbased resources (McCann, 1994: 186). Economic attraction pulled more rural youth from school, and exacerbated educational inequality as schools in company towns were better supported than those in coastal communities. Reflecting on a career in education from the 1940 s to the 1970 s, Paul Kirby commented that a lot of youngsters left school, "as soon as they were able to haul in a handline" (McCann, 1982: 144). Senator F. W. Rowe, Minister of Education between 1956 and 1959 and then again between 1967 and 1971, put these matters in stark terms:

${ }^{13}$ An anonymous reviewer of this article suggested that government neglect of rural schools may be seen as yet another support for the argument of the urban bias in the schooling project. 
Traditionally we always had to ram education down the throats of large numbers of Newfoundland people. They were concerned with the fish, they were concerned with the firewood, they were concerned with berry picking, with killing seals, with the extractive industries; as soon as a boy became big enough to get out on the flake or to get down on the stage, or to help his father in this way or that way with the vegetables, with anything else, he would be gone. (McCann, 1982: 48)

Community life stood in opposition to life in schools. ${ }^{14}$ Rowe's comments present the conception of community as "the problem," a problem ultimately solved through the outport resettlement project of the1960s. Like other rural Canadians, rural Newfoundlanders resisted the drive to remake and relocate them (Matthews, 1976; 1993).

\section{CONCLUSION: CONTEMPORARY RURAL RESISTANCE}

It is possible for an organism to become too finely tuned to a given environment to be able to survive in the face of changing environmental conditions. The same possibility may exist for remote regions that have become heavily dependent on, or closely adapted to, large scale extraction industries (Frickel and Freudenburg, 1996: 447).

Fishing is only one example of an industry that could not survive its own diligence and was obliged to sacrifice its own (deFreitas, 1997: 99).

By 1942, compulsory schooling was finally established in Newfoundland and Québec, more than half a century after similar legislation several Canadian jurisdictions. The days of the quaint isolated village down a dirt road, the co-integrated systeme agro-forestier, the schooners and men in dories were simultaneously ending. By the early 1950s, the Atlantic fishery was modernizing and mechanizing with state support (Apostle and Barrett, 1992: 169-72). Yet labour-intensive work in the fishery would remain constant for many people for many years to come and there would be a boom in the 1970s and 1980s, drawing young people to the scallop and fish draggers and into the fish plants where teenage boys in southwest Nova Scotia could make as much as a school teacher shucking scallops or cutting roe out of herring for the Japanese market (Corbett, 1991). Deck hands on draggers could make six-figure incomes in the 1980s while successful captains in the inshore fleet became millionaires. Through it all the small

${ }^{14}$ Sawyer's narrative account of teaching in a Newfoundland outport in the $1970 \mathrm{~s}$ provides a graphic illustration of the disjuncture between schooling and community life (1979). Sawyer saw liberal pedagogy as the appropriate way to bridge the gap. 
boats remained, albeit in dwindling numbers. Independent operators, the "little guys," resisted being swallowed up by big capital and resisted the lure of the kind of money a fisherman could make on the bigger boats, crewing for another man. And they remain fishing off the southwest coast of Nova Scotia.

Jacques Ferland and Christopher Wright (1996) seek to explain rurality in Canada. They argue labour history is shot through with an urban bias that promotes the erroneous assumption $20^{\text {th }}$ century Canada developed an industrial base and magically became modern. Sandwell (1994) and Bouchard (1997) argue similarly. As Donald Wilson and his students suggest, a persistent urban bias has been evident in studies of the history of Canadian education. The Canadian periphery has remained significantly influential in the lives of the many people who have lived there, and key institutions like the public school have had very different histories in rural communities.

Northrop Frye commented that in Canada's rural areas, people developed what he called a "garrison mentality." Frye claims an intimate narrowness and intensity comes from living at close quarters surrounded by a huge unknown, unpredictable geographic fact, the enormous land. In rural Canada, communities are typically buffeted by the problems and uncertainty of subsistence production and chronic migration to the urban "core" (Brym and Sacouman, 1979). Ferland and Wright suggest that with respect to labour, to communities, and to subjectivities in them, rural and

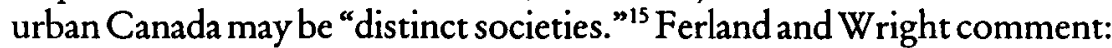

It should not be forgotten, however, that people form distinct societies and that past generations of Australian and Canadian people have not simply lived and worked in replicas of major industrial centres (1996: 142).

Atlantic Canada, for instance, provides an example of a region without a significant industrial base and in which chronic occupational uncertainty is normal.

Apostle and Barrett (1992) and Davis (1991) argue that, following World War II, the East Coast fishery was significantly capitalized and industrialized through invasive fishing technologies, creating what they term "rural industrialisation." In response to what was considered to be a backward and inefficient fishery, the federal state financed the expansion of capacity and the size of boats by offering subsidies and low interest loans

${ }^{15}$ In a recent article, popular journalist Gwynn Dyre has commented that the coming crisis for the Canadian federal system may not be linguistically based, but rather, drawn out along rural-urban lines between rich multiethnic cities and poor uni-ethnic rural areas (2001). 
for fishermen and corporations wishing to 'modernise' their operations. Transferrable fish quotes and limited entry licensing have commodified the right to have access to the resource, making it financially attractive for small boat fishing families to sell their fishing rights to the highest bidder. The result has been a changed fishery where fewer independent operators fish the traditional inshore waters while more large vessels employing crew in conditions not unlike those of factory labour fish the offshore, and fish it hard. The result has been an increasing standard of living in the region augmented by federal transfers, bought at the price of depopulation and the compromise (perhaps fatal in some places) of fish stocks.

The result for young people is that industrialisation in the fishery diminished opportunities for work in the fishery, but most radically since the most recent crisis in the East Coast fishery. Recently, young people have begun to stay in school, not because many of them want to, but because they are "getting smart" as one of the informants in the 1991 Digby County dropout study put it; they are coming to realise that opportunities in the fishery are severely limited (Corbett, 1991).

This picture of schooling between the mid-19th and mid-20th centuries is of structural conflict between community life and the local subjectivities it generates, and the project of schooling and the subjectivities the state has sought (often unsuccessfully) to produce. While in urban areas school attendance into high school had become normal, Ryerson's attendance problems of the 1840s had not been solved in marginal rural communities a full century later. In a rush to forget the inevitable importance of rural Canada, to deny the rusticity of the popular imagery that defines Canadian-ness to "important others" (that is, Europeans and particularly Americans), and to embrace the national and global state and corporatist vision, we may have cultivated an uncritical acceptance that the rural community is effectively dead in the face of the modernizing power of consumerism, bureaucracy and urbanisation (Bonner, 1997; Creed and Cheng, 1997). In an important sense, we have tried to educate modern rural communities away.

The rural community is nevertheless alive, its distinctiveness not subsumed by the state and big capital, and it is substantially different from its urban counterpart in its continuing strong ties to the land, the sea, and resources. ${ }^{16}$ In eastern coastal communities a variety of analysts have found a strong sense of family, community, and place at the heart of the modern

\footnotetext{
${ }^{16}$ Nova Scotia government export statistics from 1997 place exports of fish and fish products as the province's chief resource in terms of export dollars, more than doubling in value of wood products, the next commodity (Government of Nova Scotia, 1999).
} 
fishing economy despite modernisation (Apostle and Barrett, 1992; Kearney, 1993; Porter, 1993; Davis, 1995; Matthews, 1976; Brym and Sacouman, 1979). My own analysis of migration patterns for Digby Neck in southwestern Nova Scotia between 1963 and 1998 found that more than $60 \%$ of the population often small coastal villages remained in the local area despite a rapidly declining fishery. ${ }^{17}$ Additionally the most recent cohort in this study, those who reached 18 years of age between 1987 and 1998, were less mobile than older cohorts with more than $65 \%$ remaining in the local area (Table 1).

TABLE 1

OUTT-MIGRATION FROM DIGBY NECK BY COHORT AND DESTINATION, POTENTIAL GRADUATING CLASSES OF 1963-1998

\begin{tabular}{lcrr} 
Cohorts & N & Stayers & $\begin{array}{r}\text { Migrants } \\
50+\mathrm{km} .\end{array}$ \\
\hline $1963-74$ & 281 & $155(55.2 \%)$ & $126(44.8 \%)$ \\
$1975-86$ & 224 & $144(64.3 \%)$ & $80(35.7 \%)$ \\
$1987-98$ & 209 & $137(65.6 \%)$ & $72(34.4 \%)$ \\
\hline Total & 714 & $436(61.1 \%)$ & $278(38.9 \%)$
\end{tabular}

Although this local structure displays significant elements of sexism, xenophobia, and racism, it also offers a connection to other people and to other places that resist state regulation at any level. Such people may be those Foucault referred to as "determined inhabitants of space," standing in opposition to "pious descendants of time" (Foucault, 1986: 22). ${ }^{18}$

\footnotetext{
17The "local area" was defined by residents in the ethnographic fieldwork part of this study as being within 50 kilometres of the community of origin. For methodological details see Corbett (2001).

${ }^{18} \mathrm{Kincheloe}$ and Pinar (1991) claim that residents of the southern United States are much attached to place. They also advance the notion that southerners distrust the abstract and prefer the concrete to the theoretical. Perhaps such typically rural people, including those in rural Atlantic Canada, oppose theory because they know what it wants; it wants to digest their experience, package it and present it to foreign audiences living outside the place where those experiences actually happen. Perhaps Foucault's pious descendants of time are those who would package place in the same way rendering it meaningless in the dislocated forward march of progress or simply, history, a force that moves on regardless of individual will.
} 
Educational historians should continue to take note of this difference from urban norms, and to challenge assumptions about state hegemony and the shape of "Canadian education" as though this were a uniform entity. This work will require studies of the importance of place, of localized economies, and of social patterns in "places history forgot."

Contemporary Canadian historical scholarship has begun to explore the richness of life and the variety of forms of capitalist development. As a nation, Canada has been and continues to be "addicted to staples export" (Ferland and Wright, 1996). Life on the land and on the water remains part of experience for a significant minority of Canadian. As a consequence, the development of the institutions of social normalisation outlined by Curtis has spread out unevenly across the Canadian landscape. If education came to be firmly established in much of Canada as early as the first decades of the $20^{\text {th }}$ century, community social and economic conditions did not readily permit schooling to penetrate community life in marginal places like the British Columbian northern interior, the Canadian north in general, or Atlantic fishing communities.

As late as the 1960s frontier settlements in Western Canada provided children and their parents with a world that not unlike that of early $19^{\text {th }}$. century settlers in Ontario. As a consequence, the ability of "marginal" children to attend school on a regular basis was limited by necessity and by active resistance to school. Likewise the lure of adult roles in the community made available in a 19th-century "pre-industrial" economy (and in later co-integrated and rural industrial economies) continued, and still continues to pull many young people out of school, generating a "cocky" yet experientially-grounded resistance to the idea that school is necessary for success.

My own research suggests that levels of formal schooling remain much lower in rural communities than Canadian and provincial averages. 1996 Census micro-data show that nearly twice as many residents of a selected Nova Scotian coastal community (Western Digby Neck) have not completed any degree (including a high school diploma) compared to the Canadian average (See Table 2). 
TABLE 2

HIGHEST DEGREE ACHIEVED EXPRESSED AS A PERCENTAGE

OF THE POPULATION 15 + FOR CANADA, NOVA SCOTIA, SOUTHWEST NOVA, AND THE WESTERN DIGBY NECK CENSUS ENUMERATION AREAS, 1996

\begin{tabular}{lrrrr} 
& Canada & $\begin{array}{r}\text { Nova } \\
\text { Scotia }\end{array}$ & $\begin{array}{r}\text { Southwest } \\
\text { Nova Scotia }\end{array}$ & $\begin{array}{r}\text { Western } \\
\text { Digby Neck }\end{array}$ \\
\hline Total population 15+ & $22,678,925$ & 719,975 & 56,230 & 575 \\
No degree & 36.8 & 41.0 & 50.6 & 70.4 \\
Grade 12 Dip. & 23.1 & 17.2 & 13.7 & 14.8 \\
Trade certificate/ dip. & 10.5 & 13.9 & 14.7 & 12.2 \\
Other non-univ/ cert. & 14.1 & 13.2 & 12.1 & 1.7 \\
Some university & 2.3 & 2.4 & 6.6 & $*$ \\
Bachelor's Degree & 8.7 & 8.2 & 2.1 & $*$ \\
Above Bachelor & 3.1 & 3.2 & 1.4 & $*$
\end{tabular}

*Fewer than 10 persons. Data massaged to protect individual identities.

Source: Census of Canada 1996 micro-data.

Using 1991 labour force survey data and 1986 census material, the average educational attainment in Digby Town and Municipality was less than Grade 10 , with nearly $65 \%$ of the population never having reached high school (Corbett, 1991).

School remains peripheral for many residents of Atlantic coastal communities, and large numbers of these people have not yet been brought into the disciplinary nexus of the Canadian educational state for better and for worse. The debate about the usefulness of schooling beyond the rudimentary level is only just beginning. Only in the past couple of decades have most residents of Atlantic coastal communities agreed that extended schooling for adolescents is worthwhile. Only in the past decade, in the wake of the apparently permanent crisis in the fishery, has this idea found firm support in face of the lack of practical alternatives.

The recent crisis in the fishery has created a new set of social and economic conditions that have changed common perceptions of the value of school for working people. In other words, the context which supports prolonger formal education is the fear that fishing as a way of life is gone for good. As an informant said in Anthony Davis' study of the fishing industry on Digby Neck, "Around her ya either fish, work with fish or hang around and throw rocks at gulls. That's all there is." (1991:15) School 
and upgrading are becoming for many people, young and not so young, the alternative to throwing rocks at gulls. I suggest the entrenchment of formal secondary and post-secondary schooling as a normative practice accompanies the demise of labour-intensive rural economies. My research shows that rural schooling tends to play an ambivalent role of unintentionally ushering youth out of their communities, usually for good.

Wendell Berry claims, in The Unsettling of America (1977), that American history can be read as the story of the displacement of any group that has attempted to settle permanently and care for the land. This practice began with First Nations people, the first of a long line of people who were defined as "savages." Modern savages are more likely to be farmers or people who work in logging or fishing. Their rustic demeanour and "environmentally unfriendly" work put them outside civilised society and it is easy to condemn them and their communities to obscurity and decline. The rusticity of rural people is a primitivist notion historians of education have often taken at face value. A more careful and critical history of rural Canada will show how groups of rural dwellers have been displaced or persisted in the face of powerful forces and interests who wanted control of the spaces they inhabit.

\section{ACKNOWLEDGEMENT}

I would like to thank Don Wilson and Don Fisher as well as anonymous reviewers for comments on earlier drafts of this paper.

\section{REFERENCES}

Apostle, R. and Barrett G. (1992). Emptying theirnets Small capital and rural industrialisation in the Nova Scotian fishing industry. Toronto: University of Toronto Press.

Archibald, J. (1993). Resistance to an unremitting process: Racism, curriculum and education in Western Canada. In J. A. Mangan (ed.), The imperial curriculum Racial images and education in the British colonial experience. London and New York: Routledge: 93-109.

Ashcroft, B., Griffiths, G. and Tiffin, H. (eds.) (1995). The post-colonial studies reader. New York: Routledge.

Axelrod, P. (1997). Thepromise of schooling. Toronto: University of Toronto Press.

Berry. W. (1977). The unsettling of America Culture and agriculture. New York: Avon. 
Bhabha, H. (1994). The location of culture. New York: Routledge.

Bouchard, G. (1997). Marginality, co-integration and change: Social history as a critical exercise, Joumal of the Canadian Historical Association, n.s., 8: 19-38.

Brym R. J. and Sacouman, R. J. (eds.) (1979). Underdevelopment and social movements in Atlantic Canada. Toronto: New Hogtown Press.

Butler,J. (1997). The psychiclife of power. Stanford: Stanford University Press. Corbett, M. (1991). Dropping out in Digby. Digby N. S. The Digby District School Board.

Corbett, M. (2001). Learning to leave: The irony of schooling in a coastal community. PhD thesis, University of British Columbia.

Creed, G. W. \& Cheng, B.(1997). Recognising rusticity Identity and the power of place. In Creed,G. W. \& Cheng, B. (eds.) Knowing your place: Rural identity and cultural bierarchy. New York: Routledge.

Creese, G. and Strong-Boag, V.(eds.) British Columbia reconsidered: Essays on women. Vancouver: Press Gang Publishers.

Curtis, B. (1988). Building the educational state: Canada West 1836-71. London: Althouse.

Davey, I. E. (1978). The rhythm of work and the rhythm of school. In N. MacDonald and A. Chaiton, eds., Egerton Ryerson and his times. Toronto: Macmillan.

Davis, A. (1991). Dire straits: The case of Digby Neck and the Islands. St. John', Nfld.: ISER.

deCerteau (1984), M. The practice of everyday life. Berkeley: University of California Press.

de Frietas, E. (1997). Keel kissing bottom. No place of publication cited: Random House of Canada.

Deleuze, G. (1988). Foucault. Minneapolis: University of Minnesota Press.

Derrida, J. (1994). Spectres of Marx: The state of the debt, the work of mourning and the New International. New York: Routledge.

Donzelot, J. (1979). The policing of families. New York: Pantheon.

Dyre, G. (2001). Visible minorities, Canadian Geographic 121, 1: 44-51.

Ferland, J. and Wright, C.(1996). Rural and urban labour processes: A comparative analysis of Australian and Canadian development, Labour History, 71 (November): 142-69.

Foucault, M. (1979). Discipline and Punish. New York: Vintage.

Foucault, M. (1986). Of otherspaces. Diacritics 16, 1 (Spring): 22-7.

Frickel, S. and Freudenburg, W.R. (1996). Mining the past Historical context an the changing implications of natural resource extraction, Social Problems 43, 4, (November): 444-68. 
Fukuyama, F. (1992). The end of history and the last man. New York: Avon. Gaffield, C. (1987). Language, schooling and cultural conflict: The origins of the French language controversy in Ontario. Kingston and Montréal: McGillQueens University Press.

Giddens, A. (1981). A contemporary critique of bistorical materialism. Berkeley and Los Angeles University of California Press.

Giddens, A. (1995). Politics, sociology and social theory Encounters with classical and contemporary social thought. Stanford Stanford University Press.

Gilbert, S. B. (1997). Post-colonial theory context, practices, politics. London: Verso.

Gleason, M. (1999). Embodied negotiators Children's bodies and historical change in Canada, 1930 to1960, Joumal of Canadian Studies, 34, 1(Spring): 112-38.

Habermas, J. (1987/96). The philosophical discourse of modernity. Cambridge, Mass.: MIT Press.

Hughes, C. C. (1960). People of cove and woodlot communities from the viewpoint of social psychiatry. Vol. 2, Stirling County Study of psychiatric disorder and socio-cultural environment. New York: BasicBooks.

Johnson, D. (1999). Merchants, the state and household continuity and change in a 20th-century Acadian fishing village. Acadiensis 29, 1 (Autumn): $57-75$.

Johnson, W. (1998). The colony of unrequited dreams. Toronto: Vintage. Jones, D.C. (1978). Agriculture, the land and education. EdD thesis, UBC.

Jones, D.C. (1979). "This little mound of earth": The fate of school agriculture, in G. Tompkins ed., The curriculum in Canada in bistorical perspective, 6: 85-94.

Jones, G. (1999a). The same people in the same places? Socio-spatial identities and migration in youth, Sociology 33, 1: 1-22.

Jones, G. (1999b). Trailblazers and path followers: Social reproduction and geographical mobilityin youth. In S. Arber and C. Attias-Donfut, The myth of inter-generational conflict: The family and state in ageing societies. London and New York: Routledge.

Kach, N. and Mazurek, K.(1994). Compulsory schooling as an instrument of political and cultural hegemony A Canadian case-study. In J. A. Mangan (ed.), A significant social revolution. London: Woburn Press.

Kearney, J. (1993). Diversity of labour process, household forms, and political practice A social approach to the inshore fishing communities of Clare, Digby Neck and the Islands. Doctoral dissertation, Université Laval. 
Kincheloe, J., and Pinar, W. (eds.) (1991). Curriculum as social psychoanalysis: The significance of place. Albany: State University of New York Press.

Looker, E.D. (1993). "Interconnected transitions and their costs; Gender and urban/rural differences in transitions to work," in P. Anisef and P. Axelrod (eds.). Transitions: Schooling and employment in Canada. Toronto: Thompson Educational Publishing.

Looker, E. D. and Dwyer, P. (1998). Education and negotiated reality Complexities facing rural youth in the1990s, Youth and Society 1,1:5-22.

Lucas, R. (1971) Minetown, Milltown, Railtown: Life in Candian communities of single industry. Toronto: University of Toronto Press.

MacKay, I. (1994). The Quest for the folk: Anti-modernism and cultural selection in twentieth century Nova Scotia. Montreal and Kingston: McGillQueen's University Press.

MacLeod, A. (1999). No great mischief. Toronto: McClelland and Stewart. McCann, P. ed. (1982). Blackboards and Briefcases: Personal stories by Newefoundland teachers, educators and administrators. St. John's, Nfld.: Jesperson.

McCann, P. (1994). Schooling in a fishing society. St John's Nfld: Institute of Social and Economic Research.

Matthews, R. (1976). 'There's no better place than bere' Social change in three Newfoundland communities. Toronto: Peter Martin Associates.

Matthews. R. (1993). Controlling common property Regulating Canada's east coast fishery. Toronto: University of Toronto Press.

Miller, J. R. (1996). "To have the 'Indian' educated out of them": Classroom and class, Ch. 6 in Shingrwauk's vision: A bistory of Native residential schools. Toronto University of Toronto Press: 151-82.

Government of Nova Scotia. (1999). Resource sector export earnings, 1997. bttp//wrww.gov.ns.ca/marketing/exports/97exports.htm

Pocius, G. (1991). A place to belong Community order and everyday spaces in Calvert, Nerefoundland. Montréal and Kingston: McGill-Queens University Press.

Porter, M. (1993). Place and persistence in the lives of Nerefoundland women. Aldershot: Avebury.

Sandwell, R. W. (1994). Rural reconstruction: Towards a new synthesis in Canadian history, Histoire Sociale/Social History, 27, 53: 1-32.

Sawyer, D. (1979). Tomorrow is school and I'm sick to the beart thinking about it. Vancouver: Douglas and McIntyre.

Seyfrit, C. L. (1998). Ethnic identity and aspirations among rural Alaskan youth, Sociological Perspectives 41, 2: 343-65. 
Seyfrit, C. L. and Hamilton, L. C. (1997). Alaskan native youth and their attitudes toward education, Arctic Anthropology 34, 1: 135-48.

Seyfrit, C. L. and Danner, J. E. (1999). Social vitality and ecological planning on Virginia's Eastern Shore. Paper presented at the Conference on Rural youth and their Transitions from School to Work, Old Dominion University, Norfolk Va.

Smith, M. A. Ed. (1996). Kindling the spark: The era of one-room schools. Vancouver: British Columbia Retired Teachers Association.

Stanley, T. (1990). White supremacy and the rhetoric of educational indoctrination A Canadian case study. In J. A. Mangan (ed). The making of imperial mentalities. Manchester: Manchester University Press: 144-162.

Stephenson, P. (1995). "Mrs Gibson looked as though she was ready for the end of term": The professional trials and tribulations of rural teachers in British Columbia's Okanagan Valley in the 1920's, in J. Barman, N. Sutherland and J. D. Wilson eds., Children, Teachers and Schools in the History of British Columbia. Calgary: Detselig.

Sutherland, N. (1990). "We always had things to do": The paid and unpaid work of anglophone children between the 1920s and 1960s, Labour/Le travail 25 (Spring): 105-41.

Sutherland, N. (1991). “I can'tremember when I didn't help' The working lives of pioneer children inTwentieth Century British Columbia, Histoire sociale/Social History 24, 48 (November): 262-88.

Sutherland, N. (1995). Reflections on a century of childhood, in J. Barman, N. Sutherland and J.D. Wilson eds., Children, Teachers and Schools in the History of British Columbia. Calgary: Detselig.

Sutherland, N, (1995a). I can't recall when I didn't help: The working lives of the children of modern pioneers, in J. Barman, N. Sutherland and J. D. Wilson eds., Children, Teachers and Schools in the History of British Columbia. Calgary: Detselig.

Sutherland, N. (1995b). The triumph of formalism: Elementary schooling in Vancouver from the 1920's to the 1960's, in J. Barman, N. Sutherland and J. D. Wilson eds., Children, Teachers and Schools in the History of British Columbia. Calgary: Detselig.

Theobald, P. (1997). Teacbing the commons: Place, pride and the renewal of community. Boulder: Westview Press.

Valverde, M. (1991). The age of light, soap and water: Moral reform in English Canada. Toronto: McClelland and Stewart.

Wilson, J. D. (1989). The visions of ordinary participants: Teachers' views of rural schooling in British Columbia in the 1920's, in P. E. Roy, ed., $A$ History of British Columbia Selected readings. Toronto: Copp, Clark, Pitman. 
Wilson, J. D. (1995). "I am ready to be of assistance when I can": Lottie Bowron and rural women teachers, in J. Barman, N. Sutherland, and J.D. Wilson eds., Children, Teachers and Schools in the History of British Columbia. Calgary: Detselig.

Wilson, J. D. and P. Stortz.(1993). Education on the frontier schools: Teachers and community influence in North Central British Columbia, Histoire sociale/Social History 52 (November): 265-90.

Wilson, J. D. and P. Stortz.(1995). "May the Lord have mercy on you": The rural school problem in British Columbia in the 1920's, in J. Barman, N. Sutherland and J.D. Wilson, eds., Children, Teachers and Schools in the History of British Columbia. Calgary: Detselig.

Wright, D. (1995). Discourse, power and tradition Approach and method in recent English Canadian intellectual history, Acadiensis 24, 2 (Spring): 122-34. 